\title{
PENGARUH KONSENTRASI JUS DAUN PEGAGAN DAN PERBANDINGAN CMC DENGAN MAIZENA TERHADAP KARAKTERITIK SORBET
}

\author{
Ida Susilowati ${ }^{1)}$, Putu Ari Sandhi $\mathbf{W}^{2)}$, IDP Kartika Pratiwi ${ }^{2)}$ \\ ${ }^{1)}$ Mahasiswa PS Ilmu dan Teknologi Pangan, Fakultas Teknologi Pertanian Universitas Udayana \\ ${ }^{2)}$ Dosen PS Ilmu dan Teknologi Pangan, Fakultas Teknologi Pertanian Universitas Udayana
}

E-mail: idasusilowati695@gmail.com

\begin{abstract}
This research was conducted to determine the effect of pegagan juice and the ratio of CMC with maizena to produced the best characteristics of sorbet and to know the concentration of pegagan juice and the ratio of CMC with the right maizena to produced the best characteristics of sorbet. This study used a Completely Randomized Design (CRD) factorial consisting of two factors, the first factor is concentration of pegagan juice as follow 5\%, 7,5\%, 10\% and the second factors is ratio of CMC with maizena as follow 0:1, $0,25: 0,72,0,5: 0,5,0,75: 0,25,1: 0$. The data obtained were analyzed by analysis of variance and if the treatment have an effect on the parameters observed then continued with Duncan test. The results showed that the best characteristic of sorbet at 10\% of pegagan juice concentration and the ratio of CMC with maizena 0.75: 0.25 with the criteria of antioxidant activity $53.50 \%$, Total dissolved solids $21^{0}$ Brix, melting power $61 \%$, green color, sweet taste and a sense of pegagan rather strong and rather soft texture.
\end{abstract}

Keywords: Pegagan, cmc, maizena, sorbet

\section{PENDAHULUAN}

Sorbet merupakan salah satu jenis frozen dessert yang biasanya terbuat dari jus buah yang tinggi akan kandungan serat dan vitamin. Sorbet juga dapat dibuat dari sari buah dengan campuran air dan gula. Perkembangan di bidang pangan menyebabkan sorbet tidak hanya terbuat dari sari buah buahan, namun ada juga yang menggunakan teh dan kopi sebagai bahan pembuatan sorbet (Berkoff, 1998 dalam Rahardjo, 2015). Hal ini dapat membuka peluang sorbet menjadi pangan fungsional yang relatif murah dan bercita rasa baik serta dapat diterima masyarakat (Silalahi et al., 2014).

Berbagai jenis daun dapat dijadikan bahan untuk membuat sorbet, diantaranya adalah daun pegagan. Daun pegagan diketahui memiliki sifat fungsional yang bermanfaat bagi kesehatan tubuh karena memiliki kandungan antioksidan, selain itu pegagan diduga dapat membantu meningkatkan daya ingat. Khasiat pegagan sebagai braintonic ini sudah diuji secara kualitatif oleh Dwiyani et al, (2009) pada masyarakat Sasak penduduk asli Lombok. Winarto dan Surbakti (2003), juga menyatakan bahwa senyawa aktif dalam pegagan mampu menangkal radikal bebas sehingga dapat meningkatkan kecerdasan, meningkatkan daya ingat, merevitalisasi tubuh, memperlancar darah ke otak, melancarkan pencernaan serta sebagai daya hambat yang kuat terhadap kematian sel saraf otak. Selanjutnya berhubungan dengan aktivitas antioksidan dari pegagan, Pratiwi dan Wiadnyani (2017) menyatakan bahwa bubuk simplisia daun pegagan memiliki nilai kadar fenol berkisar antara 124,98-219,45 mg GAE/100g, kadar flavonoid berkisar antara 131,67-196,74 mgEK/100g dan aktivitas antioksidan berkisar antara 138,72 - 310,72 mgGAEAC/100g. 
Kelebihan sorbet dibandingkan dengan produk frozen dessert lainnya seperti es krim memiliki kandungan lemak yang rendah yang disebabkan karena sorbet tidak mengandung susu dan krim. Kandungan lemak yang rendah inilah yang mengakibatkan tekstur sorbet menjadi lebih kasar, oleh sebab itu dalam pembuatan sorbet memerlukan bahan penstabil. Bahan penstabil merupakan zat pembentuk gel atau bahan pengental yang banyak dimanfaatkan dalam industri makanan untuk meningkatkan kualitas sorbet. Penggunaan bahan penstabil memiliki fungsi, yaitu untuk membentuk selaput yang berukuran mikro untuk mengikat globula lemak, air, udara, dengan demikian air tidak mengkristal, dan lemak tidak akan mengeras, selain itu juga dapat mempertahankan stabilitas emulsi, memberikan keseragaman produk dan menurunkan kecepatan meleleh (Syahputra, 2008).

Carboxy Methyl Cellulose (CMC) dan maizena merupakan salah satu bahan penstabil. $C M C$ adalah turunan dari selulosa yang berfungsi sebagai pengental, stabilator, pembentuk gel, sebagai pengemulsi (Puteri et al., 2015). Maizena terdiri dari amilosa dan amilopektin, kondisi maizena yang demikian dapat mengganti fungsi pektin sebagai agensia pengental, karena maizena mempunyai kemampuan membentuk gel seperti halnya pektin (Sari, 2011). Berdasarkan latar belakang tersebut, maka dilakukan penelitian dengan tujuan mengetahui pengaruh konsentrasi jus pegagan serta perbandingan $C M C$ dengan maizena terhadap karakteristik sorbet yang dihasilkan dan untuk mengetahui konsentrasi jus pegagan serta perbandingan $C M C$ dengan maizena yang tepat untuk menghasilkan sorbet dengan karakteristik terbaik.

\section{BAHAN METODE PENELITIAN}

\section{Bahan dan Alat}

Bahan yang digunakan dalam penelitian ini adalah daun pegagan yang diperoleh dari desa Blahbatuh Gianyar, $C M C$, maizena dengan merk "Maizenaku", air, gula pasir dengan merk "gulaku", dan lemon yang diperoleh di pasar Taman Griya, sedangkan bahan kimia yang digunakan yaitu, aquades, metanol, DPPH.

Alat yang digunakan untuk pembuatan sorbet pegagan adalah pisau tahan karat, waskom, blender, panci, termometer, sendok, talenan, pengaduk, kompor, mixer, cup es krim, coolbox dan freezer, sedangkan alat yang digunakan untuk analisis meliputi timbangan analitik, kertas saring, corong, pipet tetes, tabung reaksi, pipet volume, gelas ukur, gelas beaker, handrefractometer, spektrofotometer dan vortex.

\section{Rancangan Penelitian}

Penelitian ini dilaksanakan menggunakan Rancangan Acak Lengkap (RAL) pola faktorial dengan 2 faktor. Faktor yang pertama adalah konsentrasi pegagan $(\mathrm{K})$ yang terdiri dari $(5 \%, 7,5 \%, 10 \%)$, sedangkan faktor yang kedua yaitu perbandingan $C M C$ dan maizena (P) yang terdiri dari $(0: 1)$, $(0,25: 0,75), \quad(0,5: 0,5), \quad(0,75: 0,25), \quad(1: 0)$. Masing-masing perlakuan diulang sebanyak 2 kali sehingga diperoleh 30 unit percobaan. 
Data yang diperoleh dianalisis lebih lanjut dengan sidik ragam dan apabila perlakuan berpengaruh terhadap variabel maka dilanjutkan dengan uji Duncan.

\section{Variabel yang Diamati}

Variabel yang diamati dalam penelitian ini adalah uji aktivitas antioksidan metode DPPH (Xu dan Chang (2007) dalam Pujimulyani, et al, 2010), total padatan terlarut dengan metode handrefractometer (Sudarmadji et al., 1997), daya leleh dengan metode Clark et al., 1998, dan evaluasi sensori yang meliputi rasa, aroma, tekstur, warna, dan penerimaan keseluruhan dengan metode hedonik dan skoring (Soekarto, 1985).

\section{Pelaksanaan Penelitian}

Proses pembuatan jus pegagan terdiri dari beberapa tahapan, yaitu pegagan dipotong - potong, dibersihkan dari kotoran, dan dicuci menggunakan air bersih yang mengalir. Pegagan yang sudah dicuci diblanching pada suhu $85^{\circ} \mathrm{C}$ selama 3 menit. Setelah itu pegagan yang sudah diblanching dilakukan penimbangan dan penghancuran sesuai konsentrasi yaitu $5 \%, 7,5 \%$, dan $10 \%$ dalam $77 \mathrm{ml}$ air yang ditambahkan gula pasir menggunakan blender sehingga terbentuklah jus pegagan. Jus pegagan yang sudah jadi, ditaruh ke wadah lalu ditambahkan perasan lemon, $C M C$ dan maizena sesuai perlakuan
$(0: 1,0,25: 0,75,0,5: 0,5,0,75: 0,25,1: 0)$ lalu dimixer selama 6 menit. Setelah proses pencampuran, dilanjutkan dengan penuangan pada cetakan sorbet di wadah kecil lalu didiamkan pada suhu dingin selama 24 jam sampai tercampur. Setelah 24 jam, wadah yang berisi jus pegagan tersebut dikeluarkan dari kulkas dan dilakukan pencampuran lagi menggunakan mixer selama 6 menit. Setelah itu dimasukkan kembali wadah tersebut ke dalam freezer suhu $-19^{\circ} \mathrm{C}$ selama 3 jam, lalu dilakukan pencampuran kembali dengan menggunakan mixer selama 6 menit. Langkah terakhir tersebut dilakukan pengulangan sebanyak 5 kali sampai sorbet sudah jadi.

\section{HASIL DAN PEMBAHASAN}

\section{Aktivitas Antioksidan}

Hasil analisis ragam menunjukkan bahwa interaksi antara konsentrasi pegagan dan perbandingan konsentrasi $C M C$ dengan maizena berpengaruh tidak nyata $(\mathrm{P}>0,05)$ terhadap aktivitas antioksidan pada sorbet. Perlakuan konsentrasi pegagan dan perlakuan perbandingan konsentrasi CMC dengan maizena juga berpengaruh tidak nyata $(\mathrm{P}>0,05)$ terhadap aktivitas antioksidan sorbet. Nilai rata - rata aktivitas antioksidan pada perlakuan konsentrasi pegagan dan pada perlakuan perbandingan $C M C$ dengan maizena dapat dilihat pada Tabel 1. 
Tabel 1. Nilai Rata - Rata Aktivitas Antioksidan Pada Perlakuan Konsentrasi Pegagan dan Perlakuan Konsentrasi $C M C$ dengan Maizena (\%).

\begin{tabular}{ccccccc}
\hline Perlakuan*) & P1 & $\begin{array}{c}\text { P2 } \\
(0: 1)\end{array}$ & $\begin{array}{c}\text { P3 } \\
(0,25: 0,75)\end{array}$ & $\begin{array}{c}\text { P4 } \\
(0,5: 0,5)\end{array}$ & $\begin{array}{c}\text { P5 } \\
(0,75: 0,25)\end{array}$ & Rata - Rata \\
\hline K1 $(5 \%)$ & $53,50 \mathrm{a}$ & $47,50 \mathrm{a}$ & $53,00 \mathrm{a}$ & $52,50 \mathrm{a}$ & $53,50 \mathrm{a}$ & $52,00 \mathrm{a}$ \\
K2 $(7,5 \%)$ & $47,50 \mathrm{a}$ & $51,00 \mathrm{a}$ & $52,00 \mathrm{a}$ & $53,00 \mathrm{a}$ & $59,00 \mathrm{a}$ & $52,50 \mathrm{a}$ \\
K3 $(10 \%)$ & $53,50 \mathrm{a}$ & $59,00 \mathrm{a}$ & $58,50 \mathrm{a}$ & $53,50 \mathrm{a}$ & $59,00 \mathrm{a}$ & $56,70 \mathrm{a}$ \\
Rata - Rata & $51,50 \mathrm{a}$ & $52,50 \mathrm{a}$ & $54,50 \mathrm{a}$ & $53,00 \mathrm{a}$ & $57,17 \mathrm{a}$ & \\
\hline
\end{tabular}

Keterangan : huruf yang berbeda di belakang nilai rata-rata pada baris atau kolom yang sama menunjukkan perbedaan yang tidak nyata $(\mathrm{P}>0,05)$.

*) $\mathrm{K}=$ Konsentrasi pegagan

$\mathrm{P}=$ Perbandingan $C M C$ dengan maizena

Hasil menunjukkan nilai rata - rata aktivitas antioksidan sorbet pada perlakuan konsentrasi pegagan yaitu berkisar antara 52\% - 56\%. Hal ini diduga karena jumlah penambahan pegagan yang tidak berbeda jauh sehingga antara perlakuan satu dan lainnya tidak berbeda nyata. Hasil kandungan antioksidan pada pegagan didukung oleh komponen fitokimia yang banyak terdapat pada pegagan seperti asiatikosida yang merupakan senyawa aktif dari triterpen lainnya. Menurut Mirza et al., (2013) bahwa kandungan asiatikosida pada masing-masing bagian tanaman berbeda-beda, dan tertinggi terdapat di bagian daun. Menurut Nurdin dkk (2009), bahwa senyawa antioksidan alami yang diduga banyak terdapat dalam sayuran atau dedaunan hijau adalah klorofil.

\section{Total Padatan Terlarut}

Hasil analisis ragam menunjukkan bahwa interaksi antara konsentrasi pegagan dan perbandingan konsentrasi $C M C$ dengan maizena berpengaruh sangat nyata $(\mathrm{P}<0,01)$ terhadap total padatan terlarut sorbet. Perlakuan perbandingan konsentrasi $C M C$ dengan maizena berpengaruh sangat nyata $(\mathrm{P}<0,01)$ terhadap total padatan terlarut sorbet, perlakuan konsentrasi pegagan berpengaruh tidak nyata $(\mathrm{P}>0,05)$ terhadap total padatan terlarut sorbet. Nilai rata - rata total padatan terlarut sorbet pada perlakuan konsentrasi pegagan dan perlakuan konsentrasi $C M C$ dengan maizena dapat dilihat pada Tabel 2.

Tabel 2. Nilai rata - rata total padatan terlarut sorbet ( ${ }^{0}$ Brix) pada perlakuan konsentrasi pegagan dan perlakuan konsentrasi $C M C$ dengan maizena.

\begin{tabular}{cccccc}
\hline \multirow{2}{*}{ Perlakuan*) } & P1 & P2 & P3 & P4 & P5 \\
& $(0: 1)$ & $(0,25: 0,75)$ & $(0,5: 0,5)$ & $(0,75: 0,25)$ & $(1: 0)$ \\
\hline \multirow{2}{*}{ K1 $(5 \%)$} & $19,50 \mathrm{a}$ & $20,00 \mathrm{a}$ & $19,50 \mathrm{a}$ & $20,50 \mathrm{~b}$ & $21,00 \mathrm{a}$ \\
& $\mathrm{a}$ & $\mathrm{a}$ & $\mathrm{a}$ & $\mathrm{a}$ & $\mathrm{a}$ \\
$\mathrm{K} 2(7,5 \%)$ & $21,00 \mathrm{a}$ & $19,50 \mathrm{a}$ & $19,50 \mathrm{a}$ & $21,40 \mathrm{~b}$ & $20,00 \mathrm{a}$ \\
& $\mathrm{a}$ & $\mathrm{a}$ & $\mathrm{a}$ & $\mathrm{a}$ & $\mathrm{a}$ \\
$\mathrm{K} 3(10 \%)$ & $19,00 \mathrm{a}$ & $19,50 \mathrm{a}$ & $21,00 \mathrm{a}$ & $21,00 \mathrm{~b}$ & $19,50 \mathrm{a}$ \\
& $\mathrm{a}$ & $\mathrm{a}$ & $\mathrm{a}$ & $\mathrm{a}$ & $\mathrm{a}$ \\
\hline
\end{tabular}

Keterangan: huruf yang berbeda di belakang nilai rata-rata pada baris atau kolom yang sama menunjukkan perbedaan yang sangat nyata $(\mathrm{P}<0,01)$. 
*) $\mathrm{K}=$ Konsentrasi pegagan

$\mathrm{P}=$ Perbandingan $C M C$ dengan maizena

Nilai rata - rata interaksi tertinggi dari kedua perlakuan yaitu pada perlakuan (K2P4) dengan nilai total padatan terlarut $21,40{ }^{0}$ Brix. Perlakuan perbandingan $C M C$ dan maizena (P4) berbeda sangat nyata dengan perlakuan perbandingan $C M C$ dan maizena lainnya. Pada perlakuan $\mathrm{P} 4(C M C 75 \%$ dan maizena $25 \%)$ memiliki kemampuan untuk mengikat padatan paling tinggi dibandingkan dengan perlakuan lainnya yaitu $20,97{ }^{0}$ Brix. Hal ini dikarenakan $C M C$ dan maizena memiliki sifat untuk mengikat suatu bahan, sehingga semakin banyak bahan yang diikat maka total padatan terlarutnya semakin meningkat. Hal tersebut sesuai dengan pernyataan Astuti, dkk (2016) yaitu, semakin besar konsentrasi hidrokoloid yang ditambahkan semakin besar pula zat padat yang terlarut dalam air sehingga kadar zat padat terlarutnya semakin besar pula sehingga meningkatkan nilai total padatan terlarut.

Menurut Nugraha (2003), bahwa CMC memiliki beberapa kelebihan diantaranya memiliki daya ikat air yang besar, mudah larut dalam keadaan dingin atau beku, dan juga maizena yang terdiri dari amilosa dan amilopektin dapat mengganti fungsi pektin sebagai agensia pengental, dikarenakan maizena mempunyai kemampuan membentuk gel seperti halnya pektin, selain itu pati dapat digunakan sebagai penentu struktur, tekstur, dan konsistensi bahan pangan (Sari, 2011).

\section{Daya Leleh}

Hasil analisis ragam menunjukkan bahwa interaksi antara konsentrasi pegagan dan perbandingan konsentrasi $C M C$ dengan maizena berpengaruh sangat nyata $(\mathrm{P}<0,01)$ terhadap daya leleh sorbet. Perlakuan perbandingan konsentrasi $C M C$ dengan maizena dan perlakuan konsentrasi pegagan berpengaruh sangat nyata $(\mathrm{P}<0,01)$ terhadap daya leleh sorbet. Nilai rata - rata daya leleh sorbet pada perlakuan konsentrasi pegagan dan perlakuan konsentrasi $C M C$ dengan maizena dapat dilihat pada Tabel 3.

Tabel 3. Nilai rata - rata daya leleh sorbet (\%) pada perlakuan konsentrasi pegagan dan perlakuan konsentrasi $C M C$ dengan maizena.

\begin{tabular}{cccccc}
\hline \multirow{2}{*}{ Perlakuan*) } & $\mathrm{P} 1$ & $\mathrm{P} 2$ & $\mathrm{P} 3$ & $\mathrm{P} 4$ & $\mathrm{P} 5$ \\
& $(0: 1)$ & $(0,25: 0,75)$ & $(0,5: 0,5)$ & $(0,75: 0,25)$ & $(1: 0)$ \\
\hline \multirow{2}{*}{ K1 $(5 \%)$} & $25,00 \mathrm{a}$ & $38,50 \mathrm{~b}$ & $55,00 \mathrm{c}$ & $56,00 \mathrm{c}$ & $54,00 \mathrm{c}$ \\
& $\mathrm{a}$ & $\mathrm{a}$ & $\mathrm{a}$ & $\mathrm{a}$ & $\mathrm{a}$ \\
$\mathrm{K} 2(7,5 \%)$ & $28,00 \mathrm{a}$ & $52,50 \mathrm{~b}$ & $58,50 \mathrm{c}$ & $59,50 \mathrm{c}$ & $55,00 \mathrm{c}$ \\
& $\mathrm{b}$ & $\mathrm{b}$ & $\mathrm{b}$ & $\mathrm{b}$ & $\mathrm{b}$ \\
$\mathrm{K} 3(10 \%)$ & $36,50 \mathrm{a}$ & $36,00 \mathrm{~b}$ & $51,00 \mathrm{c}$ & $61,00 \mathrm{c}$ & $57,50 \mathrm{c}$ \\
& $\mathrm{ab}$ & $\mathrm{ab}$ & $\mathrm{ab}$ & $\mathrm{ab}$ & $\mathrm{ab}$ \\
\hline
\end{tabular}

Keterangan: huruf yang berbeda di belakang nilai rata-rata pada baris atau kolom yang sama menunjukkan perbedaan yang sangat nyata $(\mathrm{P}<0,01)$.

*)K= Konsentrasi pegagan

$\mathrm{P}=$ Perbandingan $C M C$ dengan maizena 
Nilai rata - rata interaksi tertinggi dari kedua perlakuan yaitu pada perlakuan (K3P4) dengan nilai daya leleh $61 \%$. Pada perlakuan konsentrasi pegagan nilai tertinggi dimiliki oleh konsentrasi pegagan $7.5 \%$ (K2) yaitu $50,70 \%$ dan perbandingan $C M C$ dengan maizena tertinggi diperoleh pada perlakuan P4 (CMC 75\% : maizena $25 \%$ ) yaitu 58,83 \%. Hal ini dikarenakan pada sorbet ditambahkan bahan pengisi berupa pati yang dapat meningkatkan viskositas, sehingga resistensi pelelehannya lebih tinggi dan daya lelehnya menjadi lebih lama.

Daya leleh merupakan waktu yang dibutuhkan sorbet hingga meleleh sempurna pada suhu ruang. Daya leleh berkaitan erat hubungannya dengan karakteristik body dan tekstur produk (Nelson dan Trout, 1951 dalam Kesuma, 2011). Penggunaan penstabil $C M C$ pada konsentrasi yang tinggi akan meningkatkan kandungan padatan dalam adonan dan semakin banyak kandungan padatan dalam adonan menjadi lebih kental sehingga pada saat pembekuan akan menurunkan titik beku sehingga struktur produk yang dihasilkan lebih padat sehingga produk akan menjadi lambat untuk meleleh Puteri et al, 2015). Selain itu, penggunaan $C M C$ dengan bahan penstabil lainnya secara bersamaan akan menghasilkan struktur yang lebih baik ( Klose dan Glicksman 1972, dalam Nugraha, 2003). Maizena memiliki sifat membentuk gel yang kuat seperti hal nya pektin. Pektin biasa digunakan pada shorbet dan wmer ices bertujuan untuk mengurangi jumlah kristal es dan memberikan mouthfeel yang lembut (Haryadi, 1990 dalam Santoso, 2006).

\section{Karakteristik Sensoris}

Pengujian sensoris sorbet meliputi, warna, aroma, tekstur, rasa dilakukan dengan uji skoring dan uji hedonik, uji penerimaan keseluruhan menggunakan uji hedonik. Nilai rata-rata hasil analisis sensoris terhadap tekstur, warna, aroma, rasa dan penerimaan keseluruhan pada sorbet dengan uji hedonik dan uji skoring dapat dilihat pada Tabel 4.

\section{Warna}

Hasil pada Tabel 4 menunjukkan bahwa perlakuan konsentrasi pegagan dan perlakuan perbandingan $C M C$ dengan maizena berpengaruh sangat nyata $(\mathrm{P}<0,01)$ terhadap warna sorbet yang dihasilkan. Pada uji hedonik tingkat kesukaan panelis tertinggi terhadap warna sorbet diperoleh pada perlakuan K3P4 dan K3P5 yaitu 6,13 (suka), sedangkan pada uji skoring tingkat kesukaan panelis tertinggi terhadap warna sorbet diperoleh pada perlakuan K3P4 dan K3P5 yaitu 4,80 (hijau). Hal ini membuktikan bahwa peningkatan konsentrasi pegagan memberikan pengaruh terhadap warna sorbet yang dihasilkan dengan nilai tertinggi diperoleh pada perlakuan konsentrasi pegagan 10\% (K3). Warna suatu minuman akan sangat berpengaruh terhadap daya tarik konsumen pada suatu produk. Warna pada produk herbal biasanya diperoleh secara alami dari zat warna yang terdapat pada tanaman herbal. Warna minuman herbal juga sangat dipengaruhi oleh tingginya kadar klorofil pada herbal tersebut (Roni, 2008). 
Tabel 4. Nilai rata-rata hasil analisis data evaluasi sensoris terhadap tekstur, warna, aroma, rasa dan penerimaan keseluruhan pada sorbet.

\begin{tabular}{cccccccccc}
\hline \multirow{2}{*}{ Perlakuan } & \multicolumn{2}{c}{ Warna } & \multicolumn{2}{c}{ Aroma } & \multicolumn{2}{c}{ Tektsur } & \multicolumn{2}{c}{ Rasa } & Penerimaan \\
& Hedonik & Skor & Hedonik & Skor & Hedonik & Skor & Hedonik & Skor & Hedonik \\
\hline K1P1 & $4,66 \mathrm{a}$ & $2,33 \mathrm{a}$ & $4,60 \mathrm{a}$ & $2,86 \mathrm{a}$ & $3,86 \mathrm{a}$ & $2,26 \mathrm{a}$ & $4,66 \mathrm{a}$ & $1,73 \mathrm{a}$ & $4,73 \mathrm{a}$ \\
K1P2 & $4,80 \mathrm{ab}$ & $2,46 \mathrm{a}$ & $4,60 \mathrm{a}$ & $3,06 \mathrm{a}$ & $4,40 \mathrm{abc}$ & $2,73 \mathrm{bc}$ & $4,73 \mathrm{ab}$ & $2,13 \mathrm{~b}$ & $4,86 \mathrm{ab}$ \\
K1P3 & $4,86 \mathrm{abc}$ & $2,66 \mathrm{ab}$ & $4,80 \mathrm{a}$ & $3,06 \mathrm{a}$ & $4,13 \mathrm{ab}$ & $3,06 \mathrm{bc}$ & $5,06 \mathrm{abcd}$ & $2,66 \mathrm{c}$ & $4,93 \mathrm{abc}$ \\
K1P4 & $5,00 \mathrm{c}$ & $2,66 \mathrm{ab}$ & $4,80 \mathrm{a}$ & $3,06 \mathrm{a}$ & $4,46 \mathrm{bc}$ & $3,66 \mathrm{~d}$ & $5,13 \mathrm{bcde}$ & $2,73 \mathrm{c}$ & $5,26 \mathrm{bcd}$ \\
K1P5 & $5,06 \mathrm{c}$ & $2,93 \mathrm{~b}$ & $4,80 \mathrm{a}$ & $3,20 \mathrm{a}$ & $4,93 \mathrm{cde}$ & $3,93 \mathrm{de}$ & $5,46 \mathrm{defg}$ & $2,80 \mathrm{c}$ & $5,33 \mathrm{~cd}$ \\
K2P1 & $5,66 \mathrm{~d}$ & $3,86 \mathrm{c}$ & $5,26 \mathrm{~b}$ & $3,73 \mathrm{~b}$ & $4,53 \mathrm{bc}$ & $2,66 \mathrm{ab}$ & $5,06 \mathrm{abcd}$ & $3,73 \mathrm{~d}$ & $5,66 \mathrm{de}$ \\
K2P2 & $5,80 \mathrm{de}$ & $3,86 \mathrm{c}$ & $5,33 \mathrm{bc}$ & $3,80 \mathrm{~b}$ & $5,20 \mathrm{def}$ & $3,20 \mathrm{c}$ & $5,46 \mathrm{defg}$ & $3,80 \mathrm{~d}$ & $5,66 \mathrm{de}$ \\
K2P3 & $5,86 \mathrm{def}$ & $3,93 \mathrm{c}$ & $5,33 \mathrm{bc}$ & $3,80 \mathrm{~b}$ & $5,33 \mathrm{def}$ & $3,86 \mathrm{de}$ & $5,53 \mathrm{efg}$ & $3,80 \mathrm{~d}$ & $6,00 \mathrm{e}$ \\
K2P4 & $5,86 \mathrm{def}$ & $4,00 \mathrm{c}$ & $5,33 \mathrm{bc}$ & $3,87 \mathrm{~b}$ & $5,33 \mathrm{ef}$ & $4,46 \mathrm{f}$ & $5,60 \mathrm{fg}$ & $4,06 \mathrm{de}$ & $6,13 \mathrm{e}$ \\
K2P5 & $5,93 \mathrm{def}$ & $4,06 \mathrm{c}$ & $5,46 \mathrm{bcd}$ & $4,00 \mathrm{~b}$ & $5,60 \mathrm{f}$ & $4,20 \mathrm{ef}$ & $5,73 \mathrm{~g}$ & $4,06 \mathrm{de}$ & $6,00 \mathrm{e}$ \\
K3P1 & $6,00 \mathrm{ef}$ & $4,40 \mathrm{~d}$ & $5,60 \mathrm{bcd}$ & $4,20 \mathrm{bc}$ & $4,53 \mathrm{bc}$ & $2,73 \mathrm{bc}$ & $4,73 \mathrm{ab}$ & $4,40 \mathrm{ef}$ & $4,93 \mathrm{abc}$ \\
K3P2 & $6,00 \mathrm{ef}$ & $4,60 \mathrm{de}$ & $5,60 \mathrm{bcd}$ & $4,46 \mathrm{~cd}$ & $4,80 \mathrm{~cd}$ & $3,00 \mathrm{bc}$ & $4,86 \mathrm{abc}$ & $4,40 \mathrm{ef}$ & $5,33 \mathrm{~cd}$ \\
K3P3 & $6,06 \mathrm{ef}$ & $4,73 \mathrm{e}$ & $5,60 \mathrm{bcd}$ & $4,53 \mathrm{~cd}$ & $5,53 \mathrm{ef}$ & $3,93 \mathrm{de}$ & $5,20 \mathrm{cdef}$ & $4,60 \mathrm{fg}$ & $5,80 \mathrm{e}$ \\
K3P4 & $6,13 \mathrm{f}$ & $4,80 \mathrm{e}$ & $5,67 \mathrm{~cd}$ & $4,60 \mathrm{~cd}$ & $5,60 \mathrm{f}$ & $4,53 \mathrm{f}$ & $5,26 \mathrm{cdef}$ & $4,80 \mathrm{~g}$ & $5,93 \mathrm{e}$ \\
K3P5 & $6,13 \mathrm{f}$ & $4,80 \mathrm{e}$ & $5,73 \mathrm{~d}$ & $4,73 \mathrm{~d}$ & $5,73 \mathrm{f}$ & $4,33 \mathrm{ef}$ & $5,33 \mathrm{defg}$ & $4,73 \mathrm{fg}$ & $5,80 \mathrm{e}$ \\
\hline
\end{tabular}

Keterangan: huruf yang berbeda di belakang nilai rata-rata pada kolom yang sama menunjukkan perbedaan yang sangat nyata $(\mathrm{P}<0,01)$.

\section{Aroma}

Uji aroma pada sorbet menunjukkan bahwa perlakuan konsentrasi pegagan dan perlakuan perbandingan $C M C$ dengan maizena berpengaruh sangat nyata $(\mathrm{P}<0,01)$ terhadap aroma sorbet yang dihasilkan. Pada uji hedonik tingkat kesukaan panelis tertinggi terhadap aroma sorbet diperoleh pada perlakuan kosentrasi pegagan $10 \%$ dengan perbandingan $C M C$ dengan maizena 1:0 (K3P5) yaitu 5,73 (agak suka). Pada uji skoring tingkat kesukaan panelis tertinggi terhadap aroma sorbet diperoleh pada perlakuan K3P5 yaitu 4,73 (khas pegagan).
Tabel 4 menunjukkan konsentrasi pegagan mempengaruhi aroma yang dihasilkan oleh sorbet. Nilai tertinggi dimiliki oleh konsentrasi pegagan $10 \%$ (K3). Hal ini dikarenakan pegagan selain mengandung golongan senyawa triterpenoid juga mengandung minyak esensial sebesar $0,1 \%$ dari seluruh kandungan bahan aktif di dalamnya. Minyak esensial ini terbagi menjadi 2 jenis yaitu monoterpen dan sesquiterpen. Monoterpen dan sesquiterpen banyak terdapat pada jaringan parenkim daun pegagan, sehingga minyak esensial memberikan wangi atau aroma yang khas pada tumbuhan pegagan (Sutardi, 2016). 


\section{Tekstur}

Hasil uji tekstur sorbet menunjukkan bahwa perlakuan konsentrasi pegagan dan perlakuan perbandingan $C M C$ dengan maizena berpengaruh sangat nyata $(\mathrm{P}<0,01)$ terhadap tekstur sorbet yang dihasilkan. Pada uji hedonik tingkat kesukaan panelis tertinggi terhadap tekstur sorbet diperoleh pada perlakuan K3P5 yaitu 5,73 (agak suka), sedangkan pada uji skoring tingkat kesukaan panelis tertinggi terhadap tekstur sorbet diperoleh pada perlakuan K3P4 yaitu 4,53 (lembut).

Pada tabel 4 menunjukkan konsentrasi pegagan dapat mempengaruhi tekstur. Nilai tertinggi dimiliki oleh konsentrasi pegagan $10 \%$ (K3) dan perbandingan $C M C$ dengan maizena 0,75:0,25 (P4). Hal ini dikarenakan tekstur dipengaruhi oleh total padatan, semakin banyak padatan yang ditambahkan semakin meningkatkan nutrisi, dan memperbaiki body dan tekstur. Selain itu, CMC dengan maizena merupakan bahan penstabil, pengental, pengemulsi dimana memiliki fungsi untuk memperbaiki tekstur sorbet. Kestabilan diperlukan untuk mengontrol kristal es sehingga memberikan tekstur dan pelelehan yang baik.

\section{Rasa}

Hasil uji rasa sorbet menunjukkan bahwa perlakuan konsentrasi pegagan dan perlakuan perbandingan $C M C$ dengan maizena berpengaruh sangat nyata $(\mathrm{P}<0,01)$ terhadap rasa sorbet yang dihasilkan. Pada uji hedonik tingkat kesukaan panelis tertinggi terhadap rasa sorbet diperoleh pada perlakuan K2P5 yaitu 5,73 (agak suka). Pada uji hedonik tingkat kesukaan panelis tertinggi terhadap rasa sorbet diperoleh pada perlakuan K3P4 yaitu 4,80 (manis, rasa pegagan agak kuat).

Pada tabel 4 menunjukkan bahwa konsentrasi pegagan mempengaruhi rasa sorbet yang dihasilkan. Pada uji hedonik panelis agak suka terhadap sorbet dengan konsentrasi 7,5\% (K2), sedangkan pada uji skoring nilai tertinggi dimiliki pada konsentrasi pegagan $10 \%$ (K3) yaitu manis dengan rasa pegagan agak kuat. Hal ini dikarenakan pada daun pegagan memiliki rasa pahit, manis dan sepat yang dikarenakan pegagan memiliki kandungan vellarine (Dahono, 2014).

\section{Penerimaan Keseluruhan}

Uji penerimaan keseluruhan sorbet menunjukkan bahwa perlakuan konsentrasi pegagan dan perlakuan perbandingan $C M C$ dengan maizena berpengaruh sangat nyata $(\mathrm{P}<0,01)$ terhadap penerimaan keseluruhan sorbet yang dihasilkan. Nilai rata - rata tingkat kesukaan panelis tertinggi terhadap penerimaan keseluruhan sorbet diperoleh pada perlakuan K2P4 yaitu 6,13 (suka) dengan konsentrasi pegagan $7,5 \%$ dan perbandingan CMC dengan maizena $(0,75: 0,25)$. Hal ini dikarenakan semakin banyak penambahan konsentrasi pegagan panelis cenderung akan merasakan rasa pahit dan warna yang terlalu hijau tua, oleh sebab itu panelis jarang menyukainya, sedangkan pada tekstur, membuktikan bahwa semakin banyak penambahan penstabil akan membuat tekstur semakin lembut dan disukai panelis. 


\section{KESIMPULAN DAN SARAN}

\section{Kesimpulan}

Berdasarkan hasil penelitian dapat disimpulkan sebagai berikut:

1. Interaksi antara konsentrasi jus pegagan dan perbandingan $C M C$ dengan maizena tidak berpengaruh nyata terhadap aktivitas antioksidan, namun berpengaruh nyata terhadap total padatan terlarut dan daya leleh.

2. Perlakuan terbaik diperoleh dari perlakuan K3P4 dengan konsentrasi jus pegagan $10 \%$ dan perbandingan $C M C$ dengan maizena $0,75: 0,25$ dengan kriteria aktivitas antioksidan 53,50\%, daya leleh $61,00 \%$, total padatan terlarut 21,00 ${ }^{0}$ Brix, warna hijau, aroma khas pegagan, rasa manis pegagan agak kuat, dan tekstur lembut.

\section{Saran}

Berdasarkan hasil penelitian dapat disarankan sebagai berikut :

1. Untuk membuat sorbet sebaiknya menggunakanjus pegagan $10 \%$ dengan perbandingan $C M C$ dan maizena 0,75 : 0,25 .

2. Perlu dilakukan modifikasi bahan yang digunakan dan jenis penstabil lainnya dalam pembuatan sorbet.

\section{DAFTAR PUSTAKA}

Astuti, W.F.P., R.J.Nainggolan, dan M. Nurminah. 2016. Pengaruh Jenis Zat Penstabil dan Konsentrasi Zat Penstabil Terhadap Mutu FruitLeather Campuran Jambu Biji Merah dan Sirsak. Jurnal Rekayasa Pangan Dan Pertanian vol 4, No 1. Program Studi Teknologi Pangan. Universitas Sumatera Utara. Medan.
Clark, S., M. Costello., M. A. Drake., dan F. Bodyfelt. 1988. The Sensory Evaluation Of Dairy Products. Second editions, ISBN : :978-0-387-77406-0.AVI Publishing Company. New York.

Dahono. 2014. Manfaat Pegagan. www.kepri.litbang.deptan.go.id. Loka Pengkajian Teknologi Pertanian. Kepulauan Riau.

Dwiyani. H., A. Artanti., dan L. Wibisono. 2009. Pemanfaatan Tanaman Lokal Indonesia Pegagan (Centella asiatica L.) Sebagai Minuman Jelly Untuk Meningkatkan Kualitas Kecerdasan Generasi Muda Indonesia. Karya Tulis Ilmiah. Institut Pertanian Bogor. Bogor.

Kesuma.,T.,I. 2011. Pengaruh Jenis dan Konsentrasi Pati Terhadap Karakteristik Tepung Nanas (Ananas comocus (L)Merr) Dan Pengaruh CMC Terhadap Karakteristik Velva Berbahan Dasar Tepung Nanas. Skripsi. Fakultas Teknologi Pertanian. Institut Pertanian Bogor. Bogor.

Mirza, I., H. Riadi., A. Khomsan., S.A. Marliati., E. Damayanthi., dan A. Winarto. 2013. Pengaruh Ekstrak Etanol Daun Pegagan (Centella asiatica(L.) urban) Terhadap Gambaran Darah, Aktivitas, Dan Fungsi Kognitif Tikus. Jurnal Kedokteran Hewan. ISSN: 1978 225x. Institut Pertanian Bogor. Bogor.

Nugraha, R. 2003. Pengaruh Jenis dan Konsentrasi Bahan Penstabil Terhadap Mutu Produk Velva Labu Jepang ( Curcubita maxima. L). Institut Pertanian Bogor.

Nurdin., C.M. Kusharto., I. Tanziha., dan M. Zanuwati. 2009. Kandungan Klorofil Berbagai Jenis Daun Tanaman Dan CuTurunan Klorofil Serta Karakteristik Sifat Fisiko Kimianya. Jurnal Gizi dan Pangan (4):1. Institut Pertanian Bogor. Bogor.

Pratiwi, IDPK dan AAIS Wiadnyani. 2017. Capacity of Antioxidants and Flavonoids Simplicia Pegagan Leaves Powder (Centella asiatica (1) Urban). Journal of Food Security and Agriculture 1 (2) : 26-28

Pujimulyani, D., S. Rahardjo., Y. Marsono., dan U. Santoso. 2010. Aktivitas Antioksidan Dan Kadar Senyawa Fenolik Pada Kunir Putih (Curcuma mangga val.) Segar Dan Setelah 
Blanching. Jurnal Agritech, vol 30(2). Jurusan Teknologi Pangan. Universitas Gadjah Mada. Yogyakarta.

Puteri, F., R. J. Nainggolan., dan L. N. Limbong. 2015. Pengaruh Konsentrasi CMC (Carboxy Methil Cellulose) Dan Lama Penyimpanan Terhadap Mutu Sorbet Sari Buah. Jurnal Rekayasa Pangan Dan Pertanian vol 3(4). Program Studi Teknologi Pangan.Universitas Sumatera Utara. Medan.

Rahardjo, J. V. M. 2015. Pengaruh Jenis, Konsentrasi Fat Replacer Dan Freezing Time Terhadap Karakteristik Fisik Dan Aktivitas Antioksidan Pada Sorbet Kunyit Asam. Jurusan Ilmu Dan Teknologi Pangan. Fakultas Teknologi Pertanian. Universitas Katolik Soegijapranata. Semarang.

Roni, M. A. 2008. Formulasi Minuman Herbal Instan Antioksidan Dari Campuran Teh Hijau (Camellia sinensis) Pegagan (Centella asiatica), dan Daun Jerk Purut (Citrus hystrix). Fakultas Teknologi Pertanian. Bogor.

Santoso, E.N. 2006. Pengaruh Kombinasi Konsentrasi Pektin dan CMC Sebagai Bahan Penstabil Terhadap Sifat Fisikokimia Dan Organoleptik Sherbet Pepaya. Skripsi. Fakultas Teknologi Pertanian. Universitas Katolik Wifya Mandala Surabaya. Surabaya.

Sari, M. 2011. Maizena Sebagai Alternatif Pengganti Pektin Dalam Pembuatan Selai Belimbing (Averrhoa carambola L.). Jurnal Sainstek vol 3(1): $44-51$.
ISSN:2085 - 8019. Fakultas Tarbiyah IAIN Imam Bonjol Padang. Padang..

Silalahi, R. C., I. Suhaidi., dan L.N. Limbong. 2014. Pengaruh Perbandingan Sari Buah Sirsak Dengan Markisa Dan Konsentrasi Gum Arab Terhadap Mutu Sorbet Air Kelapa. Jurnal Rekayasa Pangan Dan Pertanian, vol 2(2). Program Studi Ilmu Pangan. Fakultas Pertanian. Universitas Sumatera Utara. Medan.

Soekarto, S. T. 1985. Penilaian Organoleptik untuk Industri Pangan dan Hasil Pertanian. Jakarta. Penerbit Bhratara Karya Aksara.

Sudarmadji, S., Bambang, H., dan Suhardi 1997. Analisa Bahan Makanan dan Pertanian. Liberty. Yogyakarta.

Sutardi. 2016. Kandungan Bahan Aktif Tanaman Pegagan Dan Khasiatnya Untuk Meningkatkan Sistem Imun Tubuh. Jurnal Litbang Pertanian vol. 35 (3) : 121-130. Balai Pengkajian Teknologi Pertanian Yogyakarta. Yogyakarta.

Syahputra, E. 2009. Pengaruh Jenis Zat Penstabil dan Konsentrasi Mentega Yang Digunakan Terhadap Mutu Dan Karakteristik Es Krim Jagung. Universitas Sumatra Utara. Sumatra Utara.

Winarto, W. P., dan S. Maria. 2003. Khasiat Dan Manfaat Pegagan Tanaman Penambah Daya Ingat. Penerbit PT Agromedia Pustaka cetakan pertama. Depok. 